\section{Thermostability of vaccines ${ }^{1}$}

1 Based on: World Health Organization, Global Programme for Vaccines and Immunization. Thermostability of vaccines. Geneva: WHO; 1998. (Publication WHO/GPV/98.07). Available from: http://www.who.int/gpv-documents/. Accessed 14 May 1999.
Every year the immunization services in developing countries around the world prevent more than three million deaths from measles, neonatal tetanus, and pertussis, as well as some 490000 cases of childhood paralysis from poliomyelitis. That achievement is due in part to the progress that numerous countries have made in properly transporting and storing vaccines and in better maintaining the cold chain that helps preserve vaccines' potency.

Nevertheless, those improvements have been far from uniform, and much still needs to be done to make the best use of the available vaccine resources. With that goal in mind, the Global Programme for Vaccines and Immunization of the World Health Organization (WHO) in December 1998 issued a new publication, Thermostability of Vaccines. It is an updated version of a 1989 WHO guide entitled Stability of Vaccines.

Doubts often arise as to whether or not to use stocks of vaccines that have been exposed to elevated temperatures for some period of time. Further, there is no easy, inexpensive method that can be used in the field to answer that question. Nevertheless, a knowledge of the stability of particular vaccines can help determine storage requirements and whether or not particular stocks should be used.

And that knowledge base has expanded greatly in recent years, particularly in comparison to periods in the past when all that was available was one fairly rigid set of guidelines for vaccinehandling worldwide. While that approach offered the benefit of simplicity, it led to a dogmatic view of the cold chain and prevented local health workers from making the best use of the actual heat stabilities of different vaccines. In addition, improvements in vaccines in recent years have made them more stable.

The stability of vaccines varies widely. Diphtheria and tetanus toxoids and hepatitis $B$ vaccine have the best resistance to elevated temperatures; freeze-dried measles, yellow fever, and the BCG tuberculosis vaccines are in the middle; and oral poliomyelitis vaccine is the most fragile. Reconstituted vaccines against measles, yellow fever, and tuberculosis (BCG) are unstable and should be used as soon as possible after being reconstituted. 
TABLE 1. Stability of vaccines commonly used in national immunization programs

\begin{tabular}{|c|c|c|c|c|}
\hline \multirow[b]{2}{*}{ Vaccine $^{a}$} & \multicolumn{4}{|c|}{ Storage temperature $\left({ }^{\circ} \mathrm{C}\right)$} \\
\hline & $0-8$ & $22-25$ & $35-37$ & Over 37 \\
\hline $\begin{array}{l}\text { Tetanus and diphtheria } \\
\text { toxoids as monovalent } \\
\text { vaccines or components } \\
\text { of combined vaccines }{ }^{b}\end{array}$ & Stable for $3-7$ years & Stable for months & Stable for weeks & $\begin{array}{l}\text { At } 45^{\circ} \mathrm{C} \text { : stable for } 2 \text { weeks. } \\
\text { At } 53^{\circ} \mathrm{C} \text { : loss of potency after } \\
\text { few days. } \\
\text { At } 60-65^{\circ} \mathrm{C} \text { : loss of potency after } \\
\text { few hours. }\end{array}$ \\
\hline Hepatitis $B$ vaccines ${ }^{b}$ & Stable for $2-4$ years & Stable for months & Stable for weeks & At $45^{\circ} \mathrm{C}$ : stable for days \\
\hline Measles vaccine ${ }^{c}$ & Stable for 2 years & $\begin{array}{l}\text { Retains satisfactory potency, up to } \\
50 \% \text {, for at least } 1 \text { month }\end{array}$ & $\begin{array}{l}\text { Retains satisfactory potency for at } \\
\text { least } 1 \text { week, but may lose } 20 \% \text { and } \\
50 \% \text { of potency for } 1-4 \text { day and } 2-6 \\
\text { day exposure, resp. }\end{array}$ & $\begin{array}{l}\text { At } 41^{\circ} \mathrm{C} \text { : } 50 \% \text { loss of potency after } \\
2-3 \text { day exposure. } \\
\text { At } 54^{\circ} \mathrm{C}: 80 \% \text { loss of potency after } \\
\text { 1-day exposure. }\end{array}$ \\
\hline Yellow fever vaccines ${ }^{c}$ & $\begin{array}{l}\text { Stabilized vaccines stable for 2-3 } \\
\text { years }\end{array}$ & $50 \%$ loss after $3-10$ month exposure & $50 \%$ loss after $10-20$ day exposure & $\begin{array}{l}\text { At } 46^{\circ} \mathrm{C} \text { : about } 50 \% \text { loss in potency } \\
\text { in } 2 \text { days. }\end{array}$ \\
\hline Pertussis vaccines ${ }^{b}$ & $\begin{array}{l}\text { Stable for } 18-24 \text { months, in spite of } \\
\text { continuous slow decrease in potency }\end{array}$ & $\begin{array}{l}\text { Stability varies: some vaccines stable } \\
\text { for } 2 \text { weeks }\end{array}$ & $\begin{array}{l}\text { Stability varies. Some vaccines lose } \\
50 \% \text { of potency during storage for } \\
1 \text { week }\end{array}$ & $\begin{array}{l}\text { At } 45^{\circ} \mathrm{C} \text { : about } 10 \% \text { loss of potency } \\
\text { per day. } \\
\text { At } 50^{\circ} \mathrm{C} \text { : rapid loss in potency. }\end{array}$ \\
\hline BCG vaccine ${ }^{c}$ & Stable for one year & $\begin{array}{l}\text { Stability varies: } 20 \% \text { to } 30 \% \text { loss of } \\
\text { viability during } 3 \text {-month exposure }\end{array}$ & $\begin{array}{l}\text { Stability varies; } 20 \% \text { loss of viability } \\
\text { during } 3-14 \text { day exposure }\end{array}$ & $\begin{array}{l}\text { Unstable. } \\
\text { At } 70^{\circ} \mathrm{C} \text { : } 50 \% \text { loss during } 30 \text {-minute } \\
\text { exposure. }\end{array}$ \\
\hline Oral poliomyelitis vaccine ${ }^{c}$ & Stable for $6-12$ months & $\begin{array}{l}\text { Some vaccines may retain titer for } \\
1-2 \text { week exposure }\end{array}$ & $\begin{array}{l}\text { Unstable. VVMs in use. Loss of } \\
\text { satisfactory titer in } 1-3 \text { days. }\end{array}$ & $\begin{array}{l}\text { Very unstable. At } 41^{\circ} \mathrm{C}: 50 \% \text { loss in } \\
\text { one day. } \\
\text { At } 50^{\circ} \mathrm{C} \text { : loss of satisfactory titer after } \\
1-3 \text { hour exposure. }\end{array}$ \\
\hline
\end{tabular}

a Data refer to freeze-dried measles, yellow fever, and BCG vaccines; other vaccines are presented in a fluid form. Reconstituted vaccines lose their potency quickly and they must be discarded at the end of an immunization session. Reconstituted BCG vaccine contains no bacteriostatic agent, and there is a risk of contamination. Reconstituted yellow fever vaccine should be administered quickly (up to one hour) after reconstitution. If the vaccine can be kept continuously in an ice bath, the reconstituted vaccine can be used within one immunization session. It must be discarded after the session. 
TABLE 2. Stability of other bacterial and viral vaccines

\begin{tabular}{|c|c|c|c|c|}
\hline \multirow[b]{2}{*}{ Vaccine } & \multicolumn{4}{|c|}{ Storage temperature $\left({ }^{\circ} \mathrm{C}\right)$} \\
\hline & $0-8$ & $22-25$ & $35-37$ & Over 37 \\
\hline Inactivated poliomyelitis vaccine & Stable for $1-4$ years & $\begin{array}{l}\text { Decline of D-antigen } \\
\text { content of type } 1 \text { in } \\
20 \text { days }\end{array}$ & $\begin{array}{l}\text { Loss of D-antigen of } \\
\text { type } 1 \text { content in } \\
\text { some vaccines }\end{array}$ & No precise data available \\
\hline $\begin{array}{l}\text { Meningococcal polysaccharide } \\
\text { vaccine }\end{array}$ & Stable for 2 years & $\begin{array}{l}\text { Group A vaccine: } \\
\text { stable for } 12 \text { days; } \\
\text { group } A+C \text { stable for } \\
\text { months }\end{array}$ & Half life ${ }^{\text {b: }} 4$ weeks & No data available \\
\hline $\begin{array}{l}\text { Human diploid cell rabies } \\
\text { vaccine }\end{array}$ & Stable for 3.5 years & $\begin{array}{l}\text { Retained } \\
\text { immunogenicity } \\
\text { when dispatched, } \\
\text { transported, and } \\
\text { stored for up to } 11 \\
\text { weeks }\end{array}$ & Stable for 4 weeks & No data available \\
\hline Japanese encephalitis vaccine & $\begin{array}{l}\text { Stable for one year; } \\
\text { about } 5 \% \text { loss in } \\
\text { potency during } 52- \\
\text { week storage }\end{array}$ & $\begin{array}{l}\text { Stable for } 20 \text { weeks; } \\
\text { about } 9 \% \text { loss in } \\
\text { potency during } 20 \text { - } \\
\text { week storage }\end{array}$ & $\begin{array}{l}\text { Stable for } 6 \text { weeks; } \\
\text { about } 14 \% \text { loss in } \\
\text { potency during } 18- \\
\text { week storage }\end{array}$ & $\begin{array}{l}\text { At } 40{ }^{\circ} \mathrm{C} \text { : about } 10 \% \text { loss } \\
\text { in potency after } 2 \text {-week } \\
\text { storage and } 27 \% \text { loss } \\
\text { after } 5 \text {-week storage }\end{array}$ \\
\hline $\begin{array}{l}\text { Live oral typhoid Ty21a } \\
\text { vaccine }\end{array}$ & $\begin{array}{l}\text { Needs refrigeration. } \\
\text { Shelf life depends on } \\
\text { residual moisture } \\
\text { content }\end{array}$ & $\begin{array}{l}\text { Prolonged storage } \\
\text { resulted in } \\
\text { progressively lower } \\
\text { viable counts }\end{array}$ & $\begin{array}{l}\text { Rapid decrease in } \\
\text { viable count. Retains } \\
\text { minimum potency for } \\
\text { 12-hour exposure. }\end{array}$ & No data available \\
\hline
\end{tabular}

a D-antigen content is measured in vitro by the ELISA test. IPV is standardized in D-antigen units; enhanced-potency IPV contains 40, 8, and $32 \mathrm{D}$-antigen units of types 1,2 , and 3 , respectively.

${ }^{b}$ Half life: the time at which $50 \%$ loss of original potency occurs.

Even with the most-stable vaccines, exposure to elevated temperatures results in some degradation. Table 1 provide guidelines for the vaccines that are most commonly used in national immunization programs, and Table 2 gives recommendations for other bacterial and viral vaccines. Of course, all vaccines should also be handled and used in line with their manufacturers' storage recommendations and expiry dates.

The text sections of the new WHO document provide much more extensive detail on the stability of the vaccines listed in Table 1 and Table 2, and other vaccines as well.

\section{SINOPSIS}

\section{La termoestabilidad de las vacunas}

En años recientes, muchos países han avanzado en el transporte y almacenamiento adecuado de las vacunas y han mejorado la cadena fría que ayuda a conservar su potencia. No obstante, estas mejoras se han producido de manera muy poco uniforme y aún falta mucho para que se aprovechen al máximo las vacunas disponibles. El conocer la estabilidad de ciertas vacunas puede ayudar a establecer las condiciones en que deben almacenarse y a saber si determinados lotes deben usarse o no. En este trabajo se presentan dos cuadros donde se resumen muchos datos actualizados sobre la termoestabilidad de las vacunas, según informa una nueva publicación de la Organización Mundial de la Salud. 